\title{
Effectiveness of pressure biofeedback / pbu (pressure biofeedback unit) in the process of learning of self-correction in patients with scoliosis: a pilot study
}

\author{
D Pennella ${ }^{1 *}$, F Maselli $^{2}, \mathrm{G}$ Giovannico ${ }^{3}$, M Cannone $^{4}$, A Rhainò $^{5}$, A Ciuro $^{2}$ \\ From 9th International Conference on Conservative Management of Spinal Deformities - SOSORT 2012 \\ Annual Meeting \\ Milan, Italy. 10-12 May 2012
}

\section{Introduction}

The self-correction or active correction on all levels, in the treatment of scoliosis, is now a key tool with, or without, brace treatment [1]. The primary difficulty that the patient found is to understand which muscles to activate, and how to do it to achieve significant changes in the spine, since each patient adopts a personal strategy, hardly ever fair and efficient.

\section{Aim}

The aim of this study is to verify the usefulness of the BPU to facilitate the learning processes of the SelfCorrection, in patients with adolescent idiopathic scoliosis, in free or brace treatment. Through a BPU, each patient can be facilitated, by learning a right activation of the deep muscles of the spine [2], the clinician can also objectify the course of treatment.

\section{Methods}

We enrolled 10 patients (5 for the experimental group, and 5 for control group) with adolescent idiopathic scoliosis, treated for up to 4 individual sessions of $40 \mathrm{~min}$ utes, according to a Self-correction of the scoliotic curve learning approach. Inclusion criteria:

- Adolescent Idiopathic Scoliosis

- Cobb degrees range between $15^{\circ}$ and $30^{\circ}$

- Patients with, or without, brace treatment

The control group, mean age 12.4 years, Risser 2.6 and degrees Cobb $14.8^{\circ}$, was driven to the learning of

\footnotetext{
"San Raffaele - Cittadella della Carità" Taranto, Italy

Full list of author information is available at the end of the article
}

Self-correction in the traditional way (verbal approach and passive movement) while with the experimental group, mean age 13.2 years, Risser 3 and degrees Cobb 15.2, we introduced using of the BPU to obtain the vertebral derotation [3]. Patients were subjected to analysis of posture with Formetric in $1^{\wedge}$ seated (at rest) and $2^{\wedge}$, $3^{\wedge}$ and $4^{\wedge}$ session (position of Self-correction), to evaluate the timing, and the ability to learn.

\section{Results}

The experimental group used an average of 96 minutes (2.4 sessions) to learn Self-correction, unlike the control group, which required 120 minutes (3 sessions).

\section{Conclusions}

The results of this pilot study define the usefulness of further research in this field, through an RCT of appropriate size.

\section{Author details \\ ${ }^{1 " S a n}$ Raffaele - Cittadella della Carità" Taranto, Italy. ${ }^{2}$ Genova University, Genova,Italy. ${ }^{3}$ Padova University, Padova, Italy. ${ }^{4}$ Fondazione Centri di riab. Padre Pio Foggia, Italy. ${ }^{5}$ Ist. Sant'Agostino Noicattaro, Italy.}

Published: 3 June 2013

\section{References}

1. Negrini S, Fusco C, Minozzi S, Atanasio S, Zaina F, Romano M: Exercises reduce the progression rate of adolescent idiopathic scoliosis: results of a comprehensive systematic review of the literature. Disabil Rehabil 2008, 30(10):772-785.

2. Franca FR, Burke TN, Hanada ES, Marques AP: Segmental stabilization and muscular strengthening in chronic low back pain: a comparative study. Clinics (Sao Paulo) 65(10):1013-1017. 
3. Dickson RA, Lawton JO, Archer IA, Butt WP: The pathogenesis of idiopathic scoliosis. Biplanar spinal asymmetry. J Bone Joint Surg Br 1984, 66(1):8-15.

doi:10.1186/1748-7161-8-S1-P10

Cite this article as: Pennella et al.: Effectiveness of pressure biofeedback / pbu (pressure biofeedback unit) in the process of learning of self-

correction in patients with scoliosis: a pilot study. Scoliosis 2013 8(Suppl 1): P10.

Submit your next manuscript to BioMed Central and take full advantage of:

- Convenient online submission

- Thorough peer review

- No space constraints or color figure charges

- Immediate publication on acceptance

- Inclusion in PubMed, CAS, Scopus and Google Scholar

- Research which is freely available for redistribution

Submit your manuscript at www.biomedcentral.com/submit 